\title{
GEOMORPHIC AND SEDIMENTARY IMPACTS ON THE CONTINENTAL SHELF AFTER ACCUMULATED DREDGE DISPOSAL FROM RIO DE JANEIRO HARBOR, BRAZIL
}

\author{
Gilberto Tavares de Macedo Dias ${ }^{1}$, Luiz Henrique P. Fontana ${ }^{1}$, Cleverson Guizan Silva ${ }^{1}$, \\ Rafael Cuellar de Oliveira e Silva', Uirá Cavalcanti Oliveira², Leonardo da Silva Lima', \\ José Antônio Baptista Neto ${ }^{1}$ and Estefan Monteiro da Fonseca ${ }^{1}$
}

\begin{abstract}
Marine dredging is a subaquatic excavation activity executed around the globe for various purposes by many industries. The negative impacts of dredged material discharge on benthic ecosystems are diverse. Researches on the results of dredging on estuarine geomorphology and its sedimentary regime are usual. Still, the results of dumping dredged material off the coast, in the Brazilian continental shelf, are not easily found in the literature. The present research evaluated the geomorphic disturbance resulted from discharging dredged material from Rio de Janeiro Harbor in the inner Rio de Janeiro continental shelf. Grain size analysis of the dredged and dumped sediments was compared to the inner shelf original seabed sediments. The geomorphological impact was evaluated through bathymetric and high resolution seismic and side scan sonar imagery methods. Obtained data revealed significant geomorphologic changes on the offshore bottom caused by the accumulation of compacted mud from the dredge site underlying the recent soft mud bottom of the harbor area. Besides the morphological sea bottom disturbance, sediment accumulation, and local grain size characteristics exhibited significant change, potentially impacting the surrounding benthic environment.
\end{abstract}

Keywords: seafloor geomorphology, marine sediments, marine pollution, Guanabara Bay.

RESUMO. A dragagem marinha é uma atividade de escavação subaquática executada em todo o mundo por muitas indústrias para diferentes fins. Os impactos negativos do descarte de material dragado nos ecossistemas bentônicos são diversos. Pesquisas sobre os resultados da dragagem na geomorfologia estuarina e 0 seu regime sedimentar são frequentes. Ainda assim, os resultados do despejo de material dragado ao longo da costa, na plataforma continental brasileira, não são facilmente encontrados na literatura. A presente pesquisa avaliou o distúrbio geomórfico resultante do descarte de material dragado do Porto do Rio de Janeiro na plataforma continental interna do Rio de Janeiro. A granulometria dos sedimentos dragados e descartados foi comparada com os sedimentos originais do fundo marinho na plataforma interna. 0 impacto geomorfológico foi avaliado através de métodos batimétricos, sísmica de alta resolução e imageamento por sonar de varredura lateral. Os dados obtidos revelaram mudanças geomorfológicas significativas no fundo causadas pelo acúmulo de lama compactada do local dragado, subjacente ao fundo de lama mole recente da área do porto. Além do distúrbio morfológico do fundo marinho, o acúmulo de sedimentos e as características locais de tamanho de grão apresentaram mudança significativa, potencialmente impactando 0 ambiente bentônico circundante.

Palavras-chave: geomorfologia submarina, sedimentos marinhos, poluição marinha, Baía de Guanabara.

\footnotetext{
Corresponding author: Rafael Cuellar de Oliveira e Silva

${ }^{1}$ Universidade Federal Fluminense, Post-graduate Program in Ocean and Earth Dynamics, Caixa Postal 106051, CEP 24230-971, Niterói, RJ, Brazil - E-mails: gilbertotmd@id.uff.br, Ihpfontana88@gmail.com, cguizan@id.uff.br, rafaelsilva@id.uff.br, leodslima@gmail.com, jabneto@id.uff.br, oceano25@hotmail.com

${ }^{2}$ Ministério dos Transportes, Portos e Aviação Civil. Secretaria de Infraestrutura Portuária. Departamento de Obras e Serviços em Empresas Vinculadas; SCN Quadra 04, Bloco B, Edifício Varig - Pétala C, $12^{\circ}$ andar - CEP 70.714-900, Brasília, DF, Brazil - E-mail: uira.oliveira@transportes.gov.br
} 


\section{INTRODUCTION}

Shallow coastal zones represent some of the most productive environments of the ocean. However, these areas are under increasing pressure from human activities worldwide (Halpern et al., 2008). The economy of many coastal areas is directly connected to the capacity of their waterways and harbors. Unfortunately, not all locations are naturally or permanently deep enough as required for harbor activity. Most areas adjacent to harbors or waterways are characteristically shallow and continued dredging of these areas is usually needed to maintain minimal operational standards. This produces large amounts of sediments that must be reallocated (Harvey et al., 1998; Brown \& Collier, 2008; Van Maren et al., 2014; Manap \& Voulvoulis, 2016). Nowadays, one of the major environmental issues is precisely the disposal of this material in the environment, which is usually done in the continental shelf in Brazil, generating great impact in these areas. The environmental impact due to the dredging and dumping processers are of great concern in the scientific community. For instance, previous studies of dredge spoil dumping have demonstrated a range of large to long-term impacts on benthic communities (Harvey et al., 1998; Cruz-Motta \& Collins, 2004; Bolam et al., 2006; Bolam, 2012; Bolam et al., 2016; Cunning et al., 2019). Due to the relative mobile incapacity of most benthic species, excavated material disposal in open-sea sites may be more harmful to benthic fauna than to any other part of the marine ecology (Clarke \& Warwick, 1994; Powilleit et al., 2006; Bolam, 2012). Scientific literature suggested significant differences in disposal effects on the macrofauna, ranging from smaller scale (Smith \& Rule, 2001) to significant community-structure impacts (Harvey et al., 1998; Roberts et al., 1998; Bolam et al., 2006), concluding that the potential ecological results of each project must be studied separately (Harvey et al., 1998; Cruz-Motta \& Collins, 2004; Bolam, 2011; Manap \& Voulvoulis, 2016).

The impact intensity caused by disposal of dredged material depends on many variables, such as the volume of removed material, the disposal technique, the physical characteristics of the discarded sediment and hydrodynamic patterns at the discharge location (Cole et al., 1999).

The environmental impact of geomorphic modifications related to dredging activities have been described on the literature (Monge-Ganuzas et al., 2013; Van Maren et al., 2014), however few authors evaluated the impact of dumping dredged sediments in the open marine environment. Moreover, only few studies considered the short- and long-term effects ( $>1$ year) of contaminated dredged material disposal (Du Four \& Van Lancker, 2008).

The periodic sub-bottom dredging and dumping activities can incur great costs, and can also result in significant disturbances in sediment distribution and seabed morphology (Wienberg \& Bartholoma, 2005). Therefore, economically and environmentally sound dredging and dumping operations require not only an evaluation of the mobility and dispersion pattern but the potential negative ecological effects caused by the dumping and dispersion of the dredged material. Obviously multidisciplinary studies that integrate various techniques are central to achieve such objectives.

Based on the above-mentioned information, the present study aimed to verify the impacts of geomorphologic modifications and changes in sediment texture associated with the dredged material discharge on the continental shelf adjacent to Guanabara Bay.

\section{STUDY AREA}

Rio de Janeiro Harbor, located in Guanabara Bay, represents one of the most relevant harbors in Brazilian coast. Its access is ensured by regular maintenance and permanent dredging of the outer navigation channel. Guanabara Bay is one of the largest bays on the Brazilian coastline (Fig. 1). This area represents the second largest industrialized center in the country, with over 12,000 industries, including two oil refineries (Baptista Neto et al., 2006; Fonseca et al., 2009). Approximately more than 2,000 commercial vessels dock in Rio de Janeiro Harbor annually, making it the second largest harbor in Brazil (Kjerfve et al., 1997; Soares-Gomes et al., 2016). In the last 100 years, the catchment area around Guanabara Bay has been strongly modified by human activities. It is surrounded by the second most important metropolitan area of the country (Amador, 2012), accounting for $25 \%$ of the organic pollution released to the bay waters. Over recent decades, land disturbance and urbanization in the surrounding area has significantly increased sediment input and all kind of pollution to the bay and had a negative effect on its overall environment (Baptista Neto et al., 2013). Previous studies have pointed out Guanabara Bay as one of the most polluted ecosystems in Brazil (Rebello et al., 1986; Kjerfve et al., 1997; Carreira et al., 2002; Baptista Neto et al., 2006; Covelli et al., 2012; Vilela et al., 2014; Soares-Gomes et al., 2016; Nascimento et al., 2018; Aguiar et al., 2018), with indications that the bay may export pollutants, including heavy metals, to the coastal area (Melo et al., 2014). 


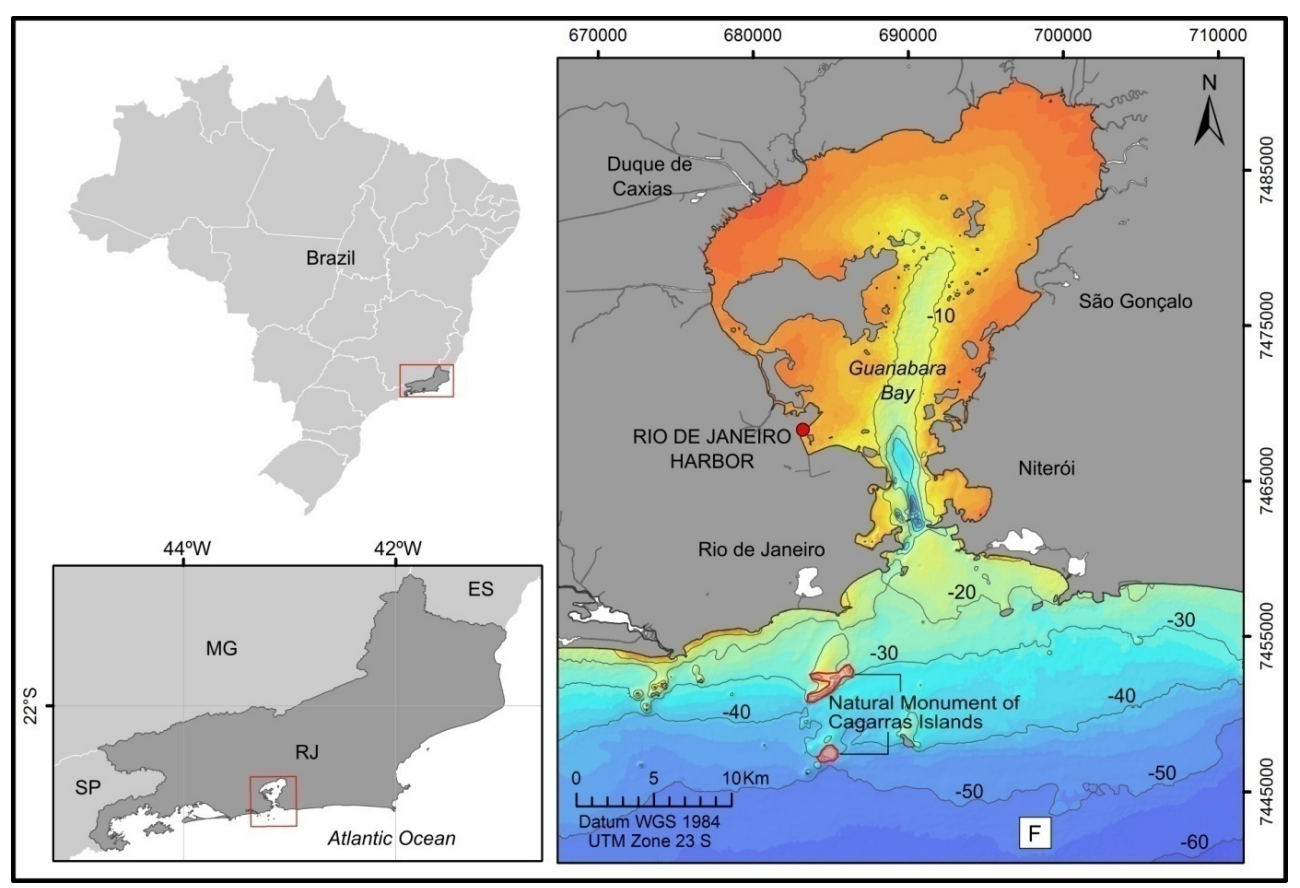

Figure 1 - Study area locating the Rio de Janeiro Harbor inside Guanabara Bay and the disposal site (F) on the inner continental shelf.

According to environmental regulations, the local authorities don't permit dredged sediment discharges inside the estuary. Presently the sediment disposal site is located on the continental shelf in a previously licensed spot, shown in Figure 1. The disposal site lies in water depths of nearly $50 \mathrm{~m}$, in a moderate energy continental shelf, affected by the passage of winter frontal systems. According to Lazzari et al. (2019), the modern surface sediment in the southeast shelf is covered by very fine siliciclastic sands and silts with variations in the clay and calcium carbonate contents; however, coarser sand and gravels are generally derived from relict sediments, deposited under low sea level intervals (Milliman \& Summerhayes, 1975; Kowsmann, 1979; Mahiques et al., 2002). The dumping site is located in relative proximity (nearly $13 \mathrm{~km}$ ) to the Natural Monument of Cagarras Islands, officially recognized by the Brazilian Environmental Agency as a conservancy and integral environmental protected area. The dumping area is also in the vicinity of active artisanal fishing communities located in the cities of Rio de Janeiro, São Gonçalo and Niterói (Fig. 1) and there is insufficient knowledge about the potential impact of the dumping on these activities.

\section{MATERIALS AND METHODS}

A total of 20 surface sediment samples were taken on the dredging site before the dredging activity began in 2014, in order to evaluate the nature of the sediment that would be excavated and dumped. The subsamples were disaggregated and dry sieved on a column with mesh sizes every $1 / 4$ phi, ranging between 2000 and $710 \mu \mathrm{m}$. After carbonate elimination, the sand fraction was sieved similarly in a range between 710 and $75 \mu \mathrm{m}$. Finally, the mud fraction (when present) was analyzed using a Micromeritics SediGraph 5100. Grain size distribution curves and sedimentological parameters of each sample (mean grain size, sorting and skewness) were calculated.

In order to compare the sediment textural changes, we used a set of 17 samples collected in one control area adjacent to the dumping site, considered to represent the original seabed sediments, in similar water depths (Fig. 2). After the dredging disposal started, we collected superficial samples with a Van Veen grab sampler in 13 stations in the dumping site. These stations were re-occupied in December 2015, May 2016 and August 2016 (Fig. 2). All samples were subjected to the same treatment and analysis above-mentioned.

Geophysical surveys were conducted using Chirp sub-bottom profiler in November 2015, and side scan sonar and single-beam bathymetry in April 2016 and in May 2017 (Fig. 2), to analyze sea bottom geomorphology impacts.

Side scan sonar imagery (EdgeTech 4100, 100-500 kHz) were acquired, covering an area of $4 \mathrm{~km}^{2}$ along 18 survey lines. Sonograms were processed with CODA software and converted into georeferenced images. Single-beam bathymetry 

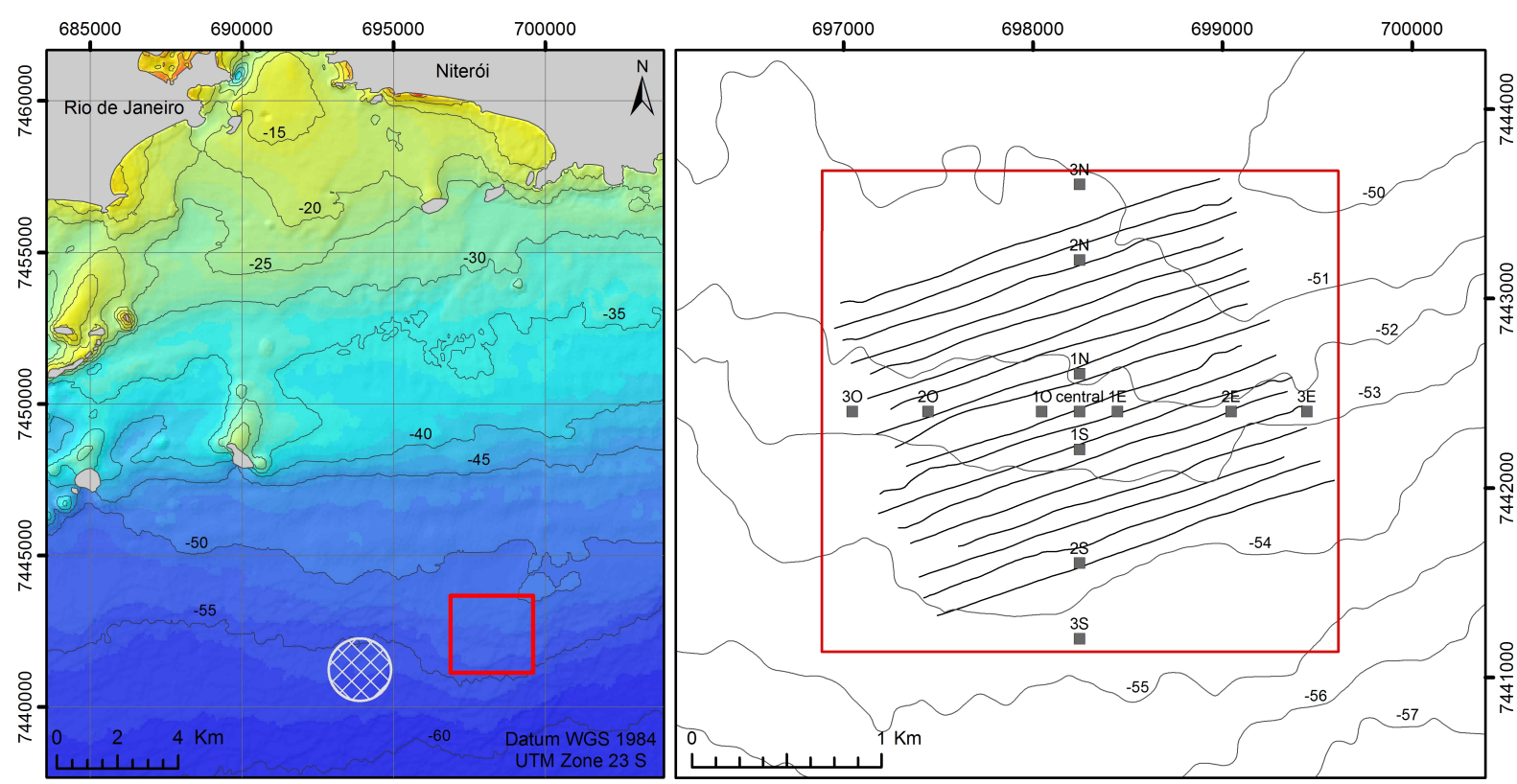

Figure 2 - The map on the left shows the location of the dumping site (red rectangle) and the control area selected to represent the original seabed sediments (white circle). On the right the location of samples and geophysical survey lines inside the dumping site (red box).

was carried out with an OHMEX SonarMite connected to a DGPS. A Chirp sub-bottom profiler survey (Edge Tech SB-216S sub-bottom profiler/ acquisition frequency from $2 \mathrm{kHz}$ to $10 \mathrm{kHz}$ ) was conducted to define the thickness of the dredged sediment deposit. The software Discover-Edge Tech and Seismic Unix were used for seismic processing to increase the quality of seismic images.

\section{RESULTS}

The original seabed sediment on the continental shelf in the dumping site was dominated by medium to very fine quartzose sands (Fig. 3). The dredged material from Rio de Janeiro Harbor has on average $51 \%$ silt, $21 \%$ clay, and $18 \%$ sand. Figure 3 represents the original sediments of the continental shelf compared with those from the harbor area and the changes in sediment texture after disposal. It is possible to observe the enrichment in fine particles, as well as in coarse sand and pebbles, confirming the strong textural difference after the dumping started to occur (Fig. 3). Table 1 presents the complete results of grain size analysis of sediment samples collected at the dumping site on different dates. Table 2 shows the complete results of grain size analysis of sediment samples collected at the control area (baseline), representing the original superficial sediments of the continental shelf. Table 3 shows the results of the grain size analysis from sediment samples collected on Rio de Janeiro Harbor before dredging activities started in 2014. The dredged material dumped on the continental shelf also contains a large amount of stiff mud as confirmed by underwater images taken by a drop-camera (Fig. 4).

The acquired sub-bottom high resolution seismic data in the dumping site show the original seabed surface delineated by the strong bottom reflector adjacent to the dumping loads (blue dashed line in Fig. 5). The sub-bottom reflector (red in Fig. 5) represents the original stratigraphy. Successive dredge spoils are observed on the sedimentary mound (green and yellow dashed lines in Fig. 5). In Figure 6, we show five CHIRP profiles illustrating the accumulated spoil over the original seabed, showing as much as 8 meters of thickness over the original seabed in the central portion of the dumping site (Profile 08 in Fig. 6), evidencing the prior accumulation of dredged sediments, before the bathymetric and sonographic surveys were conducted in the area.

The first bathymetric survey in 2016 was done after the dredging material was already displaced on the dumping site. Two mounds were observed in the north and central areas (Fig. 7), locally accumulating nearly $8 \mathrm{~m}$ of dredged material over the original water depths of circa $54 \mathrm{~m}$. Unfortunately, the original project did not cover the entire area to the north of the dumping mound. As seen in Figure 7, the northern mound clearly extends to the north, beyond the surveyed area. Nevertheless, this 


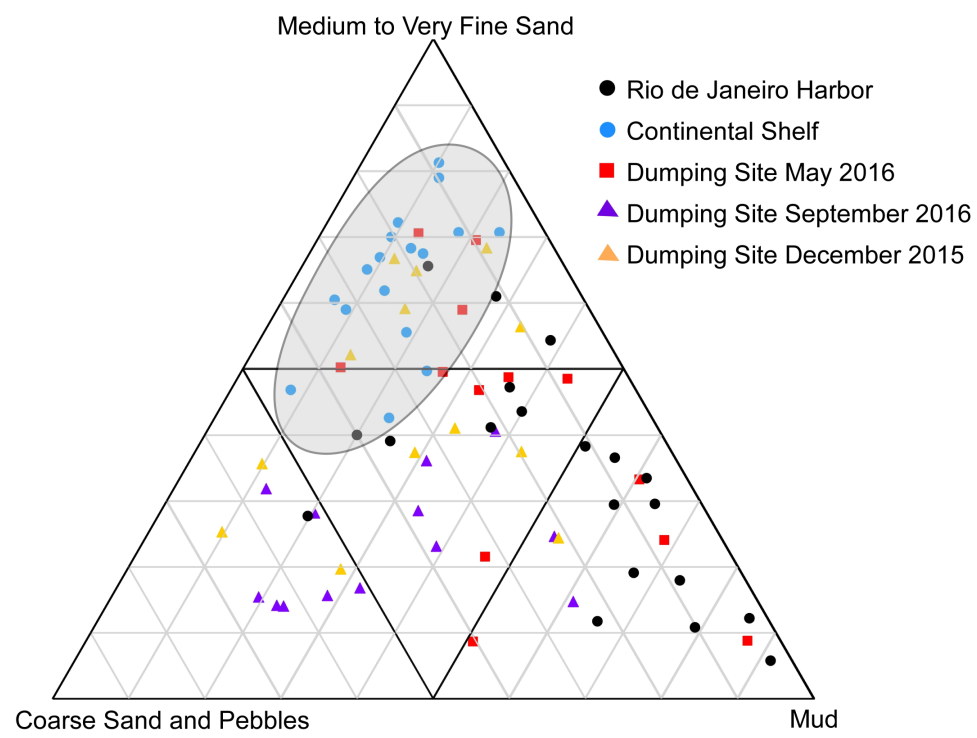

Figure 3 - Ternary plot showing the particle size distribution of the samples from the dredged area (Rio de Janeiro Harbor), samples representing the original continental shelf and samples collected after dumping started to occur (December 2015, May 2016 and August 2016).

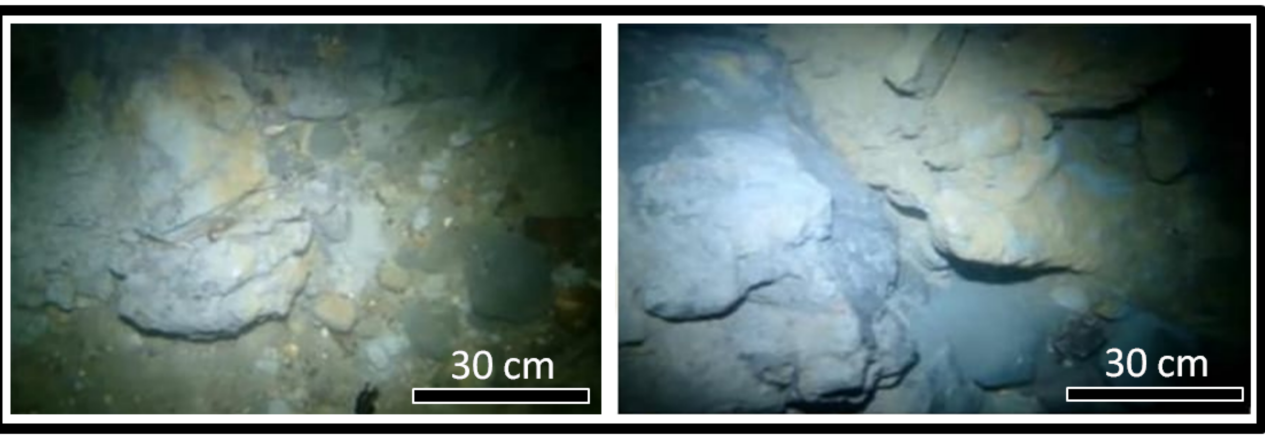

Figure 4 - Drop-camera images from the dumping site showing blocks of stiff mud laying on the seabed. Source: Photos provided by Otto Sobral.

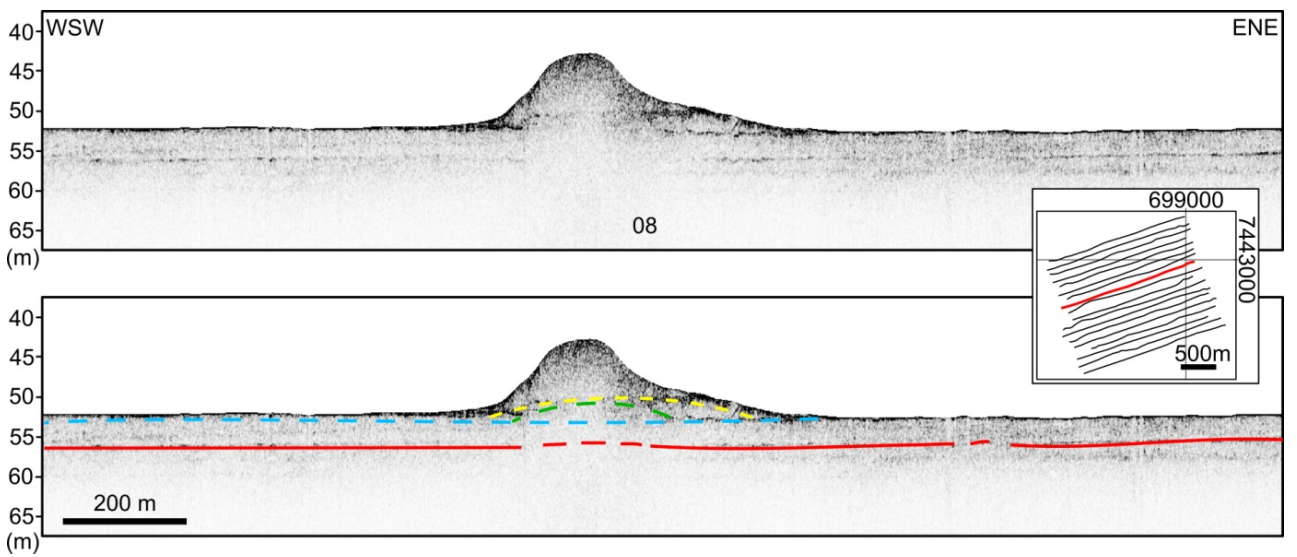

Figure 5 - Chirp sub-bottom seismic profile showing accumulation located over the original parallel flat bottom (blue dashed line). Red line represents a natural, ancient sea bottom surface. Green and yellow are successive surfaces of dredge spoil deposits. Above: non-interpreted seismic section; below: interpreted seismic section. 
Table 1 - Grain size analysis of samples collected at the dumping site.

\begin{tabular}{|c|c|c|c|c|c|c|c|c|c|}
\hline Station & $\begin{array}{l}\text { Pebble } \\
(\%)\end{array}$ & $\begin{array}{l}\text { Very coarse } \\
\text { sand (\%) }\end{array}$ & $\begin{array}{l}\text { Coarse } \\
\text { sand (\%) }\end{array}$ & $\begin{array}{l}\text { Medium } \\
\text { sand (\%) }\end{array}$ & $\begin{array}{c}\text { Fine } \\
\text { sand (\%) }\end{array}$ & $\begin{array}{l}\text { Very fine } \\
\text { sand (\%) }\end{array}$ & $\begin{array}{l}\text { Silt } \\
(\%)\end{array}$ & $\begin{array}{l}\text { Clay } \\
(\%)\end{array}$ & Sampling date \\
\hline Central & 13.1 & 15.6 & 25.8 & 27.9 & 6.4 & 1.3 & 6.6 & 3.2 & December 2015 \\
\hline $1 \mathrm{~N}$ & 3.8 & 6.0 & 9.8 & 17.1 & 15.6 & 4.7 & 37.9 & 5.0 & \\
\hline $2 \mathrm{~N}$ & 6.8 & 8.2 & 11.6 & 16.7 & 19.0 & 5.4 & 19.7 & 12.8 & \\
\hline $3 N$ & 19.2 & 19.8 & 13.3 & 9.6 & 6.3 & 3.8 & 24.0 & 4.1 & \\
\hline $1 \mathrm{~S}$ & 14.4 & 9.8 & 9.4 & 19.4 & 15.5 & 2.4 & 19.2 & 9.8 & \\
\hline $2 S$ & 3.0 & 5.1 & 13.5 & 44.0 & 14.6 & 8.2 & 7.0 & 4.6 & \\
\hline $3 S$ & 1.6 & 5.3 & 27.8 & 24.6 & 13.7 & 13.9 & 9.1 & 4.0 & \\
\hline $1 \mathrm{~L}$ & 1.2 & 3.7 & 5.3 & 10.0 & 37.9 & 8.5 & 27.3 & 6.0 & \\
\hline $2 \mathrm{~L}$ & 4.4 & 4.9 & 10.4 & 22.8 & 25.8 & 16.3 & 12.2 & 3.2 & \\
\hline $3 \mathrm{~L}$ & 1.0 & 2.7 & 5.0 & 10.7 & 30.3 & 27.4 & 14.0 & 8.9 & \\
\hline 10 & 5.6 & 7.1 & 8.5 & 11.9 & 8.0 & 4.5 & 50.4 & 4.0 & \\
\hline 20 & 0.8 & 3.1 & 20.1 & 43.2 & 11.0 & 5.1 & 12.0 & 4.8 & \\
\hline 30 & 1.4 & 26.3 & 37.3 & 21.6 & 1.6 & 2.1 & 7.0 & 2.6 & \\
\hline Central & 0.8 & 3.7 & 12.2 & 36.3 & 30.9 & 3.2 & 11.9 & 0.9 & May 2016 \\
\hline $1 \mathrm{~N}$ & 0.0 & 1.9 & 2.5 & 2.8 & 3.6 & 2.4 & 51.1 & 35.9 & \\
\hline $2 \mathrm{~N}$ & 9.1 & 18.0 & 13.3 & 4.7 & 2.4 & 1.6 & 21.8 & 29.0 & \\
\hline $3 N$ & 10.0 & 11.9 & 10.6 & 10.9 & 7.4 & 3.2 & 38.9 & 7.1 & \\
\hline $1 \mathrm{~S}$ & 2.4 & 4.2 & 10.2 & 24.2 & 31.4 & 3.3 & 19.6 & 4.8 & \\
\hline $2 S$ & 0.2 & 3.6 & 3.9 & 9.3 & 13.1 & 1.6 & 26.0 & 42.2 & \\
\hline $3 S$ & 4.2 & 15.9 & 17.0 & 26.1 & 22.0 & 2.0 & 12.5 & 0.2 & \\
\hline $1 \mathrm{~L}$ & 2.1 & 3.2 & 4.4 & 19.2 & 44.4 & 5.8 & 20.8 & 0.1 & \\
\hline $2 \mathrm{~L}$ & 0.2 & 1.2 & 6.8 & 17.7 & 20.5 & 10.2 & 20.6 & 22.8 & \\
\hline $3 \mathrm{~L}$ & 0.2 & 1.4 & 4.8 & 11.0 & 8.7 & 13.5 & 22.9 & 37.6 & \\
\hline 10 & 5.0 & 9.6 & 6.1 & 14.3 & 26.4 & 6.0 & 29.0 & 3.6 & \\
\hline 20 & 0.4 & 2.1 & 13.7 & 28.4 & 14.7 & 5.3 & 32.9 & 2.4 & \\
\hline 30 & 0.9 & 2.9 & 20.3 & 44.3 & 4.0 & 1.2 & 11.2 & 15.3 & \\
\hline Central & 10.3 & 24.8 & 16.1 & 13.0 & 3.7 & 0.2 & 28.0 & 3.9 & August 2016 \\
\hline $1 \mathrm{~N}$ & 28.0 & 20.6 & 14.7 & 10.4 & 3.7 & 0.2 & 21.0 & 1.3 & \\
\hline $2 \mathrm{~N}$ & 9.2 & 19.1 & 27.7 & 27.6 & 4.1 & 0.2 & 10.6 & 1.5 & \\
\hline $3 N$ & 19.5 & 27.0 & 18.7 & 13.0 & 2.3 & 0.2 & 18.1 & 1.2 & \\
\hline $1 S$ & 19.9 & 8.1 & 9.6 & 21.1 & 7.2 & 0.3 & 29.2 & 4.5 & \\
\hline $2 S$ & 20.7 & 25.0 & 16.8 & 11.9 & 2.1 & 0.2 & 21.8 & 1.4 & \\
\hline $3 S$ & 5.8 & 6.4 & 9.3 & 29.4 & 9.9 & 1.4 & 37.2 & 0.7 & \\
\hline $1 \mathrm{~L}$ & 5.0 & 15.5 & 17.6 & 18.3 & 4.5 & 0.4 & 36.2 & 2.6 & \\
\hline $2 \mathrm{~L}$ & 2.0 & 8.1 & 14.1 & 10.2 & 3.8 & 0.8 & 60.2 & 0.8 & \\
\hline $3 \mathrm{~L}$ & 1.1 & 7.2 & 13.5 & 13.9 & 7.2 & 3.6 & 50.3 & 3.3 & \\
\hline 10 & 2.5 & 25.1 & 28.4 & 15.1 & 0.4 & 0.3 & 27.9 & 0.3 & \\
\hline 20 & 5.8 & 17.3 & 28.3 & 24.5 & 3.5 & 0.2 & 15.4 & 4.9 & \\
\hline 30 & 1.6 & 4.4 & 26.8 & 34.2 & 1.9 & 0.1 & 22.9 & 8.2 & \\
\hline
\end{tabular}




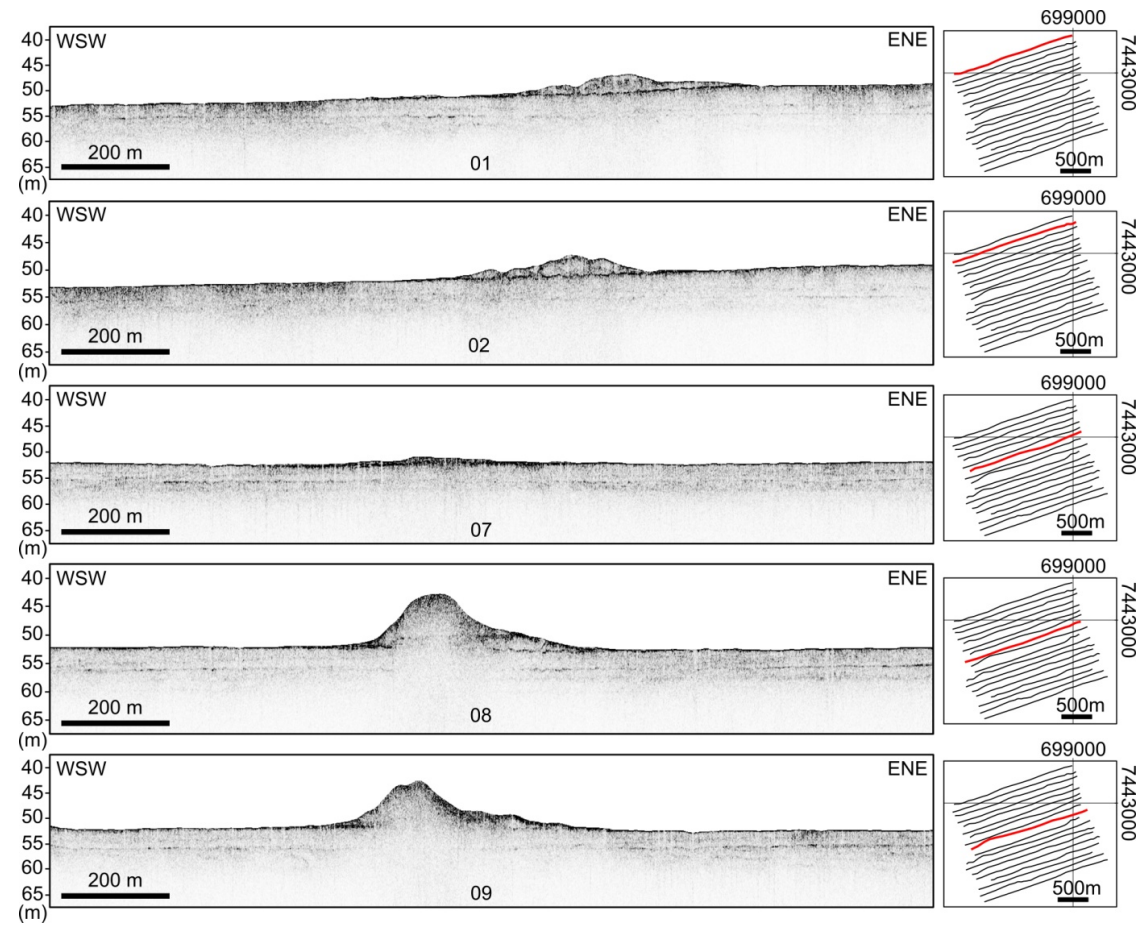

Figure 6 - CHIRP profiles showing the accumulated disposals on the north and central portions of the dumping site. Vertical depth in meters below sea level.

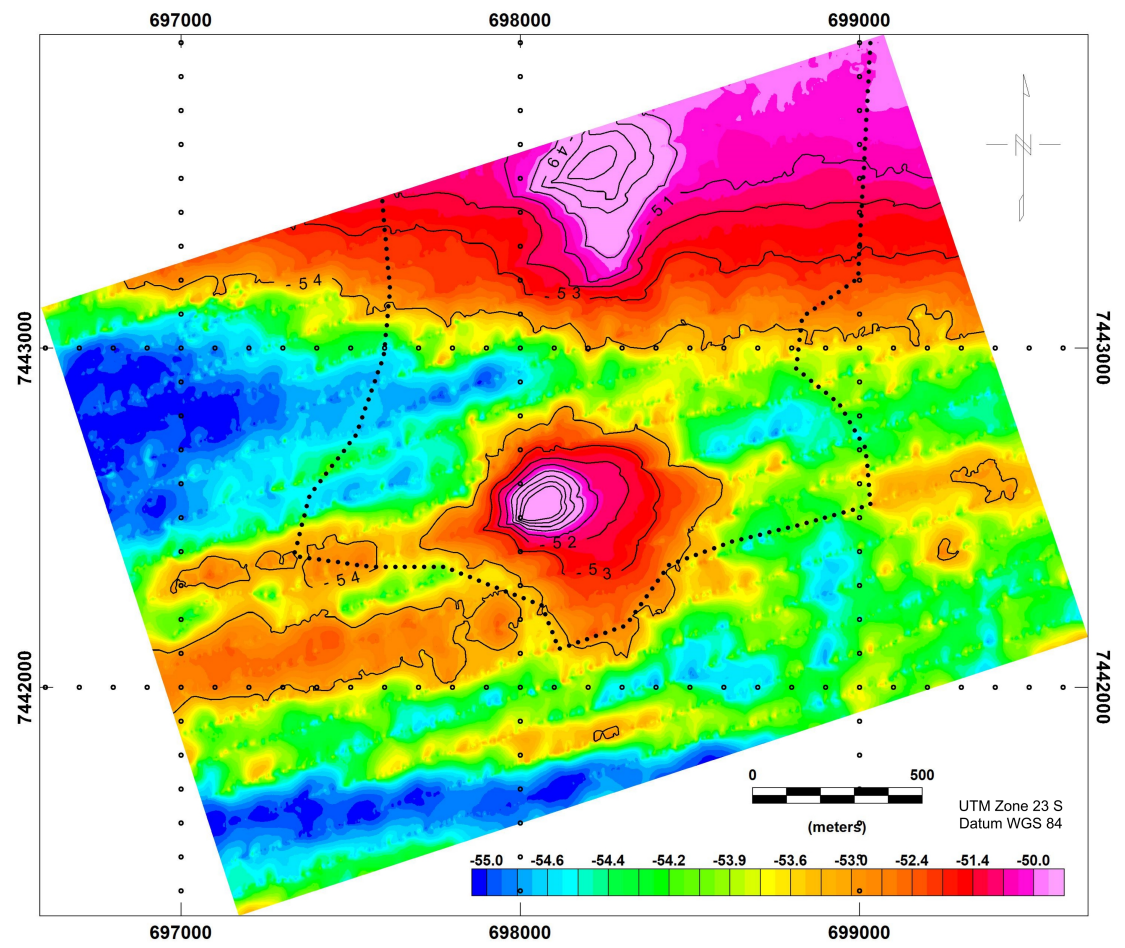

Figure 7 - Bathymetric map after 2016 survey. Depth in meters. Dotted polygon represents the area considered to calculate the volume of disposed sediments between 2016-2017. 
Table 2 - Grain size analysis of samples collected at the control area (original superficial sediments of continental shelf).

\begin{tabular}{|c|c|c|c|c|c|c|c|c|}
\hline Station & $\begin{array}{c}\text { Pebble } \\
(\%)\end{array}$ & $\begin{array}{c}\text { Very coarse } \\
\text { sand (\%) }\end{array}$ & $\begin{array}{c}\text { Coarse } \\
\text { sand (\%) }\end{array}$ & $\begin{array}{c}\text { Medium } \\
\text { sand (\%) }\end{array}$ & $\begin{array}{c}\text { Fine } \\
\text { sand (\%) }\end{array}$ & $\begin{array}{c}\text { Very fine } \\
\text { sand (\%) }\end{array}$ & $\begin{array}{c}\text { Silt } \\
(\%)\end{array}$ & $\begin{array}{c}\text { Clay } \\
(\%)\end{array}$ \\
\hline 1 & 3.7 & 6.4 & 8.5 & 18.3 & 22.1 & 27.8 & 6.7 & 6.4 \\
2 & 0.9 & 2.0 & 2.9 & 3.6 & 15.9 & 51.2 & 12.6 & 10.9 \\
3 & 0.4 & 3.4 & 7.3 & 8.7 & 17.0 & 45.0 & 8.3 & 9.9 \\
4 & 1.3 & 3.3 & 5.0 & 10.7 & 27.2 & 41.0 & 7.8 & 3.7 \\
5 & 4.2 & 7.8 & 13.9 & 19.9 & 19.0 & 26.1 & 7.9 & 1.1 \\
6 & 3.2 & 5.6 & 8.6 & 14.7 & 15.4 & 37.4 & 10.2 & 4.9 \\
7 & 4.7 & 12.8 & 27.6 & 19.3 & 10.4 & 17.1 & 5.4 & 2.7 \\
8 & 4.2 & 6.3 & 7.9 & 13.4 & 22.1 & 36.7 & 7.2 & 2.3 \\
9 & 2.9 & 6.0 & 11.4 & 15.0 & 17.7 & 37.3 & 6.9 & 2.8 \\
10 & 3.3 & 7.7 & 12.4 & 14.5 & 23.9 & 28.6 & 8.4 & 1.3 \\
11 & 3.7 & 6.9 & 15.2 & 18.4 & 9.4 & 21.8 & 11.8 & 12.8 \\
12 & 2.8 & 8.6 & 22.9 & 12.3 & 14.8 & 15.4 & 2.6 & 20.5 \\
13 & 0.7 & 2.9 & 4.9 & 14.9 & 26.0 & 40.3 & 5.6 & 4.7 \\
14 & 2.3 & 9.3 & 20.9 & 24.9 & 15.0 & 20.5 & 5.7 & 1.3 \\
15 & 3.9 & 8.4 & 13.0 & 13.8 & 14.1 & 33.9 & 10.3 & 2.5 \\
16 & 4.7 & 9.1 & 18.0 & 21.9 & 8.8 & 28.3 & 6.6 & 2.6 \\
17 & 3.7 & 9.0 & 12.9 & 12.2 & 12.7 & 30.8 & 16.0 & 3.0 \\
\hline
\end{tabular}

does not affect our main results once we compared successive bathymetric surveys in the same areas performed in 2016 and 2017.

The disposal accumulation is clearly observed after the second bathymetric survey executed in 2017 (Fig. 8). The comparison of bathymetric maps elaborated after successive surveys in 2016 and 2017 revealed that the study area has undergone major morphological changes (Figs. 7 and 8). Sediments clearly accumulated on the central/north part of the old dumping site, extending the sediment pile on the edge towards the north, presenting an approximate relief of nearly $8 \mathrm{~m}$ above the regional original bathymetry before sediment disposal. The data herein suggested that the total area covered by the dumped sediment covered $50 \%$ of the total disposal area. Only at the deeper locations (>54 $\mathrm{m}$ ) the bottom depth remained the same. The polygon common to the two elaborated bathymetric maps from years 2016 and 2017 (Figs. 7 and 8) has an area of 2,300,000 $\mathrm{m}^{2}$ and the accumulated volume of dumped sediments in one year is nearly $1,150,000 \mathrm{~m}^{3}$.

In the present study the original background sediments was dominated by quartzose medium to very fine sand, with carbonate shell fragments. Figure 9 shows the sonographic survey executed in 2016, when the sediment disposal was already occurring in the area for at least two years. The original seabed 


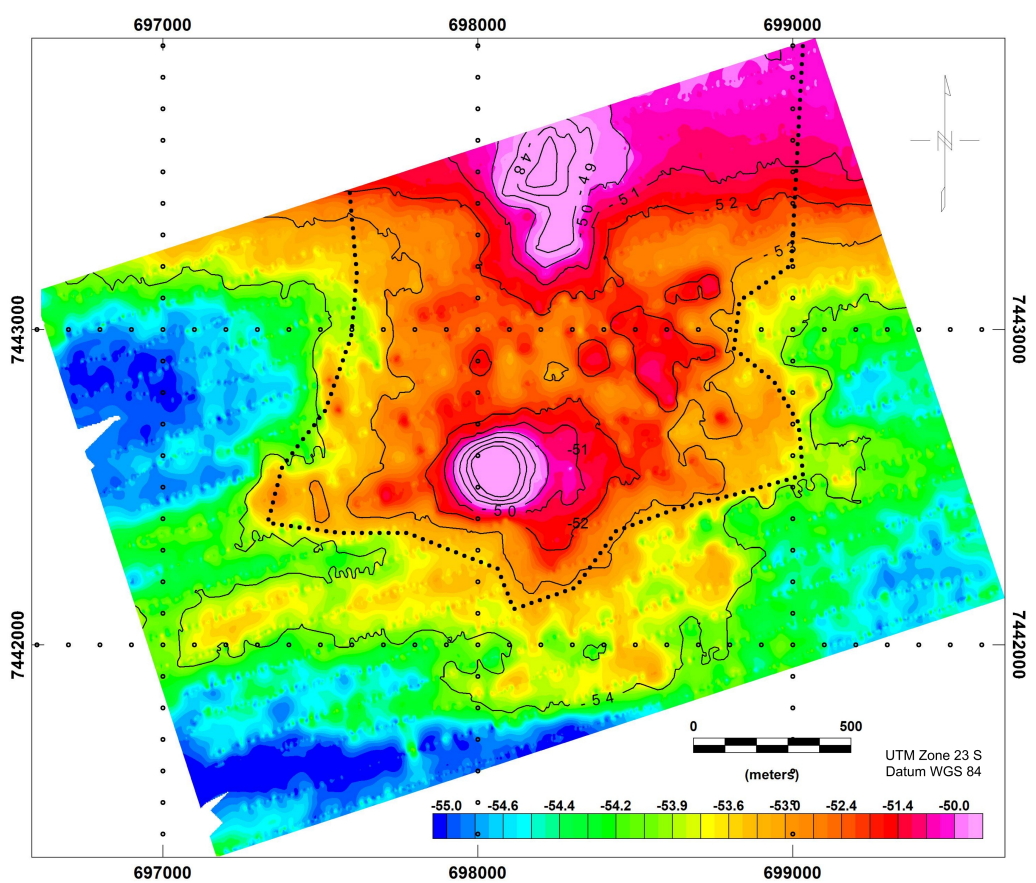

Figure 8 - Bathymetric map after 2017 survey. Depth in meters. Dotted polygon represents the considered area to calculate the volume of disposed sediments between 2016-2017.

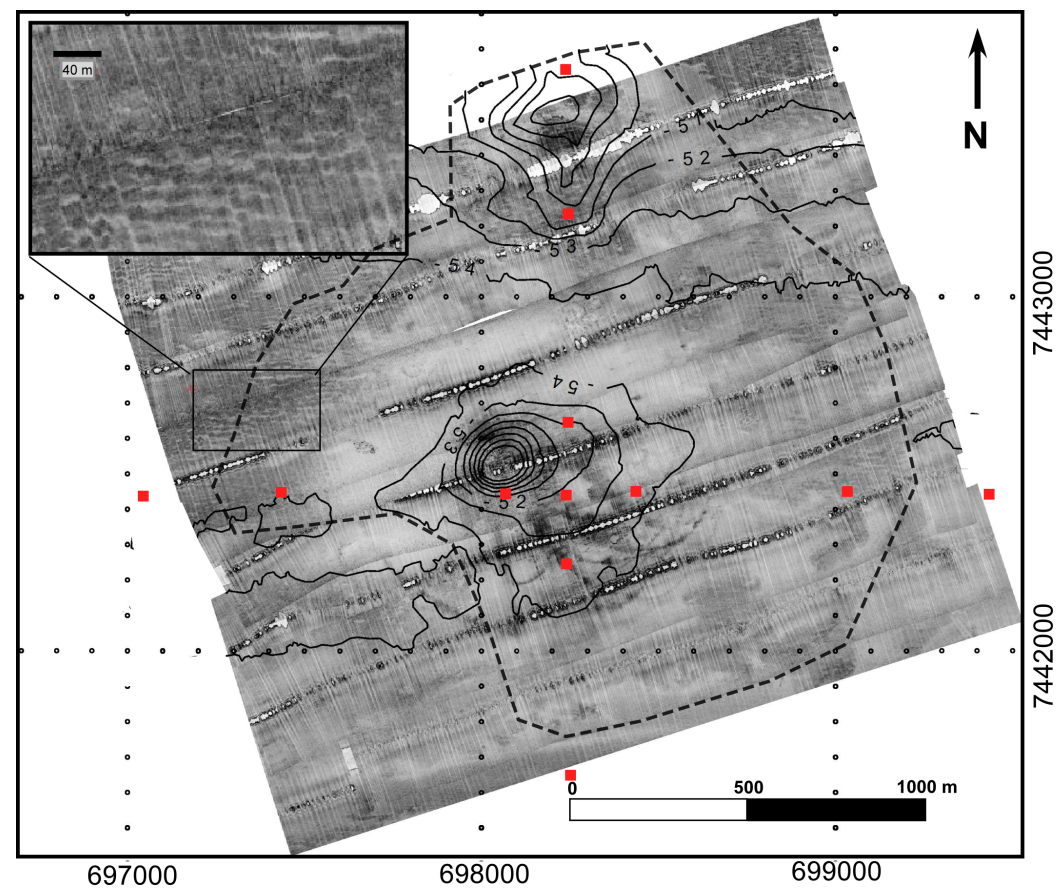

Figure 9 - Sonographic mosaic from 2016 survey. Bathymetric contours are in meters. Red squares are the superficial sample stations. Dashed line polygon indicates the area mostly affected by dredge disposal (after 2017, see Fig. 10). The insert shows the original seabed with mega-ripples. 
Table 3 - Grain size analysis of samples collected at Rio de Janeiro Harbor before dredging started in 2014.

\begin{tabular}{|c|c|c|c|c|c|c|c|c|}
\hline Station & $\begin{array}{c}\text { Pebble } \\
(\%)\end{array}$ & $\begin{array}{c}\text { Very coarse } \\
\text { sand (\%) }\end{array}$ & $\begin{array}{c}\text { Coarse } \\
\text { sand (\%) }\end{array}$ & $\begin{array}{c}\text { Medium } \\
\text { sand (\%) }\end{array}$ & $\begin{array}{c}\text { Fine } \\
\text { sand (\%) }\end{array}$ & $\begin{array}{c}\text { Very fine } \\
\text { sand }(\%)\end{array}$ & $\begin{array}{c}\text { Silt } \\
(\%)\end{array}$ & $\begin{array}{c}\text { Clay } \\
(\%)\end{array}$ \\
\hline 1 & 1.0 & 0.8 & 0.9 & 0.7 & 2.4 & 2.7 & 43.2 & 48.1 \\
2 & 0.0 & 9.5 & 10.9 & 20.4 & 15.1 & 3.1 & 0.9 & 33.8 \\
3 & 13.7 & 5.2 & 3.6 & 5.7 & 4.1 & 2.0 & 27.6 & 38.2 \\
4 & 7.5 & 20.6 & 24.5 & 22.0 & 4.4 & 1.4 & 11.7 & 8.0 \\
5 & 7.5 & 4.5 & 2.0 & 1.5 & 9.7 & 7.9 & 33.0 & 33.7 \\
6 & 5.3 & 4.2 & 1.3 & 1.8 & 24.8 & 11.7 & 36.6 & 14.2 \\
7 & 6.1 & 11.3 & 18.7 & 22.0 & 15.7 & 1.4 & 16.7 & 8.2 \\
8 & 1.5 & 2.2 & 1.5 & 9.5 & 16.4 & 7.5 & 29.9 & 31.4 \\
9 & 5.3 & 3.1 & 1.7 & 3.2 & 3.5 & 4.2 & 35.9 & 43.2 \\
10 & 0.8 & 0.9 & 0.6 & 2.7 & 5.7 & 3.8 & 59.7 & 25.6 \\
11 & 4.9 & 3.3 & 8.3 & 22.9 & 15.0 & 5.7 & 28.1 & 11.8 \\
12 & 5.8 & 1.6 & 1.2 & 1.0 & 8.7 & 8.3 & 44.8 & 28.7 \\
13 & 3.3 & 1.5 & 1.3 & 2.2 & 18.5 & 8.8 & 36.3 & 28.0 \\
14 & 3.2 & 2.5 & 2.1 & 4.3 & 21.3 & 11.0 & 55.3 & 0.3 \\
15 & 18.9 & 8.4 & 12.6 & 19.1 & 19.2 & 1.6 & 18.9 & 1.1 \\
16 & 5.5 & 2.1 & 3.6 & 19.9 & 33.3 & 7.8 & 19.1 & 8.7 \\
17 & 3.2 & 2.6 & 1.6 & 3.4 & 40.4 & 10.6 & 32.5 & 5.8 \\
18 & 6.7 & 5.1 & 4.5 & 9.5 & 30.2 & 7.6 & 27.8 & 8.6 \\
19 & 6.2 & 5.2 & 6.4 & 21.7 & 35.1 & 8.8 & 15.1 & 1.5 \\
20 & 6.7 & 2.6 & 2.2 & 5.3 & 15.7 & 8.4 & 21.0 & 38.0 \\
\hline
\end{tabular}

is characterized by the dark gray backscatter with mega-ripples, observed on the northwest and northeast corners of the mosaic, having nearly $20 \mathrm{~m}$ of wavelength (Fig. 9). Local circular dark features represent compact mud dumped in the area as was confirmed by drop-camera images (Fig. 4). These features are coincident with two bathymetric highs, having areas of circa $100,000 \mathrm{~m}^{2}$ and $30,000 \mathrm{~m}^{2}$ (central and north bathymetric highs, respectively) (Fig. 8). Figure 10 shows the mosaic after the 2017 sonographic survey illustrating the advance of dredged sediment disposal, now encompassing an area of nearly 2,300,000 $\mathrm{m}^{2}$. This area is represented by the polygon traced in Figure 10 which was placed over Figure 9 for comparison.

\section{DISCUSSIONS}

The impacts of dredging and disposal of sediment on the marine habitat are not unique to the Brazilian continental shelf. These problems have attracted attention worldwide (Gibbs \& Angelidis, 1989; Cruz-Motta \& Collins, 2004; Bolam et al., 2006; Ware et al., 2010; Crowe et al., 2010; Bolam, 2012; Chung et al., 2017). The disposal of excavated material can have a negative impact on the marine environment and, depending on the local hydrodynamics, such impacts may not only be restricted to the immediate area of dumping. Several authors (Cruz-Motta \& Collins, 2004; Bolam et al., 2006; Bolam, 2012; Bolam et al., 2016; Cunning et al., 2019) using previous 


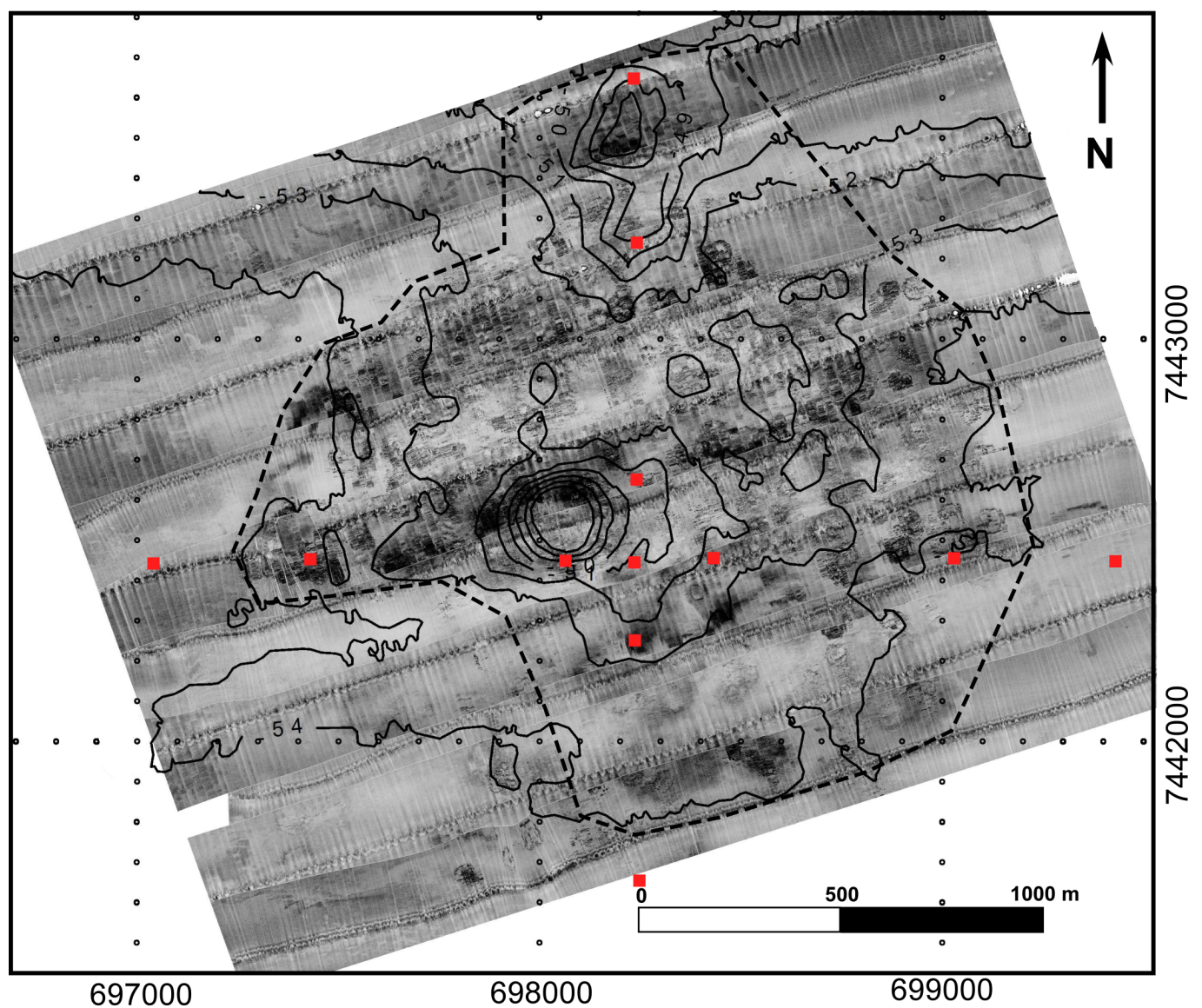

Figure 10 - Sonographic mosaic from 2017 survey. The advance of dump accumulation is clearly seen as circular, highly reflective features above the intermediate to low reflective original sea bottom. Bathymetric contours in meters. Red squares are the superficial sample stations. Dashed line polygon indicates the area mostly affected by dredge disposal.

monitoring programs and field and laboratory-based experiments clearly demonstrate that the level and scale of impact is related to a number of important attributes of the dredge spoil, such as sedimentological change, heavy metal contamination, polycyclic aromatic hydrocarbons, microplastics, etc. (Tauber, 2009; Rumney et al., 2015; Chung et al. 2017; Baptista Neto et al., 2019). Fine sediments can potentially increase pollution, including heavy metals derived from urban runoff. As pointed out by Melo et al. (2014), the Guanabara Bay can export pollutants, including heavy metals to the coastal area.

On the continental shelf and at the bay entrance, quartzose sand facies predominates, and according to previous studies (Figueiredo Jr \& Tessler, 2004) on the inner continental shelf, in $50 \mathrm{~m}$ water depth, where the disposal site is located, the sediment is mostly median to very fine quartzose sand as was also confirmed by our grain size analysis on sediment samples from the control area. Our results show a change in the original sediment texture, confirming an increase in fine particles, augmenting the potential of environmental pollution impact on the vicinities of the dumping site. More investigations should be conducted in order to understand the real negative results in the adjacent ecological communities.

Open sea dumping of dredged sediment is a common practice adopted by the major harbors in Brazil. It is common sense of local Brazilian authorities that the regular distribution of dredged material through a wider area tends to be less harmful than the concentration in a more punctual dumping site. However, in order to control environmental impacts, evaluating the trajectory to avoid the flux of the sediment to ecological sensible spots is fundamental. If the dumping location for dredged material is not chosen properly for the sediment characteristics, substantial volumes of disposed material could 
invade surrounding ecologically important sites for aquatic life. Therefore, it is necessary to study the excavated sediment characteristics and evaluate its disposition in seabed.

The physical recovery of dumping sites after disposal cessation so far has only been sporadically reported in the literature. Wienberg \& Hebbeln (2005) observed the regeneration of "dunes" after the end of the dumping activities in the Wesser Estuary, while Stronkhorst et al. (2003) observed a recovery of sediment texture at a dumping site in the North Sea, near the harbor of Rotterdam. This was not the case observed in the disposal site from Guanabara Bay, at least during the 3-year monitoring period interval.

Tauber (2009) investigated repeated side scan sonar mosaics in dumping sites at the Baltic Sea, showing that after three years, the mounds created by dumping material were eroded and the coarser material remained at the surface, while the fine material filled in the gaps between the highs. After three years, the dumping mounds on the area under investigation in the Rio de Janeiro continental shelf are still remaining, which is most probably due to the presence of compact mud from the Rio de Janeiro Harbor dredging material which were not dispersed by the hydrodynamics on the continental shelf in the investigated area. Besides the direct impact on the benthic fauna, this morphologic change of the original seabed may constitute another environmental impact factor.

\section{CONCLUSIONS}

The relationship among seafloor bathymetry, seabed morphology, side scan sonar images, high resolution seismic data and sediment grain size distribution provided new insights to evaluate the environmental disturbance resulting from dumping dredged material in the continental shelf off Guanabara Bay.

The disposal site on the Rio de Janeiro inner continental shelf was chosen by local authorities considering its hydrodynamic capacity and related potential for proper dispersion of the dredging material. However, the obtained results revealed changes in seabed morphology after dumping of dredged stiff cohesive mud, which were not dispersed by bottom currents. Dumping has caused an observable depth reduction in most of the disposal site, suggesting that future dredging and dredge spoil dumping operations from the Rio de Janeiro Harbor should take into consideration the sediment characteristics, not only grain size, to evaluate the risks of morphological changes on dumping site and its influence on local ecology. Sediment grain size changes were also indicated three years after the dredged material dumping started, increasing the percentage of fine and coarse fractions on the original predominantly medium to very fine sandy seabed. The enrichment in fine sediments increases the potential of accumulation of pollutants, especially heavy metals, exported from the Guanabara Bay contributing to the current debate: "what is less harmful, the discharge of sediments in a punctual spot or the dispersion through a pre-defined wider area?".

\section{ACKNOWLEDGMENTS}

The authors are grateful to Otto Sobral for permitting to publish the drop-camera images presented in Figure 4. Special thanks are due to the anonymous reviewers. This work was supported by the Secretaria de Portos (SEP), Ministry of Infrastructure, Brazil.

\section{REFERENCES}

AGUIAR VMC, ABUCHACRA PAF, BAPTISTA NETO JA \& OLIVEIRA AS. 2018. Environmental assessment concerning trace metals and ecological risks at Guanabara Bay, RJ, Brazil. Environmental Monitoring and Assessment, 190: 448-465.

AMADOR ES. 2012. Bacia da Baía de Guanabara: características geoambientais, formação e ecossistemas. Rio de Janeiro, Brazil. Interciência, 432 pp.

BAPTISTA NETO JA, GINGELE FX, LEIPE T \& BREHME I. 2006. Spatial distribution of trace elements in surficial sediments from Guanabara Bay - Rio de Janeiro/Brazil. Environmental Geology, 49: 1051-1063.

BAPTISTA NETO JA, PEIXOTO TCS, SMITH BJ, MCALISTER JJ, PATCHINEELAM SM, PATCHINEELAM SR \& FONSECA EM. 2013. Geochronology and heavy metal flux to Guanabara Bay, Rio de Janeiro state: a preliminary study. Anais da Academia Brasileira de Ciências, 85(4): 1317-1327.

BAPTISTA NETO JA, CARVALHO DG, MEDEIROS K, DRABINSKI TL, MELO GV, SILVA RCO, PORTO DC, BATISTA LS, DIAS GTM, FONSECA EM \& SANTOS FILHO JR. 2019. The impact of sediment dumping sites on the concentrations of microplastic in the inner continental shelf of Rio de Janeiro/Brazil. Marine Pollution Bulletin, 149: 110558.

BOLAM SG. 2011. Burial survival of benthic macrofauna following deposition of simulated dredged material. Environmental Monitoring and Assessment, 181: 13-27.

BOLAM SG. 2012. Impacts of dredged material disposal on macrobenthic invertebrate communities: A comparison of structural and functional (secondary production) changes at disposal sites around England and Wales. Marine Pollution Bulletin, 64: 2199-2210.

BOLAM SG, MCILWAINE PSO \& GARCIA C. 2016. Application of biological traits to further our understanding of the impacts of dredged material disposal on benthic assemblages. Marine Pollution Bulletin, 105: 180-192. 
BOLAM SG, REES HL, SOMERFIELD P, SMITH R, CLARKE KR, WARWICK RM, ATKINS M \& GARNACHO E. 2006. Ecological consequences of dredged material disposal in the marine environment: $A$ holistic assessment of activities around the England and Wales coastline. Marine Pollution Bulletin, 52: 415-426.

BROWN CJ \& COLLIER JS. 2008. Mapping benthic habitat in regions of gradational substrata: An automated approach utilizing geophysical, geological, and biological relationships. Estuarine Coastal Shelf Science, 78: 203-214.

CARREIRA RS, WAGENER AL, READMAN JW, FILEMAN TW, MACKO SA $\&$ VEIGA A. 2002. Changes in the sedimentary organic carbon pool of a fertilized tropical estuary, Guanabara Bay, Brazil: an elemental, isotopic and molecular marker approach. Marine Chemistry, 79: 207-227.

CHUNG CS, SONG KH, CHOI KY, KIM YI, KIM HE, JUNG JM \& KIM CJ. 2017. Variations in the concentrations of heavy metals through enforcement of a rest-year system and dredged sediment capping at the Yellow Sea-Byung dumping site, Korea. Marine Pollution Bulletin, 124: 512-520.

CLARKE KR \& WARWICK RM. 1994. Change in marine communities: an approach to statistical analysis and interpretation. Plymouth Marine Laboratory, UK. 2nd ed., 144 pp.

COLE RG, O'SHEA S, GLASBY CJ \& IMMENGA D. 1999. Biological effects of disposal of Marina Channel dredgings in the shallow subtidal of a fetch-limited embayment. In: Proceedings of XIV Austral-Asian Coastal and Engineering Conference and VII Austral-Asian Port and Harbour Conference. Australia. pp. 125-128.

COVELLI S, PROTOPSALTI I, ACQUAVITA A, SPERLI M, BONARDI M \& EMILI A. 2012. Spatial variation, speciation and sedimentary records of mercury in the Guanabara Bay (Rio de Janeiro, Brazil). Continental Shelf Research, 35: 29-42.

CROWE SE, GAYES PT, VISO RF, BERGQUIST DC, JUTTE PC \& VAN DOLAH RF. 2010. Impact of the Charleston Ocean Dredged Material Disposal Site on nearby hard bottom reef habitats. Marine Pollution Bulletin, 60: 679-691.

CRUZ-MOTTA JJ \& COLLINS J. 2004. Impacts of dredged material disposal on a tropical soft-bottom benthic assemblage. Marine Pollution Bulletin, 48: 270-280.

CUNNING R, SILVERSTEIN RN, BARNES BB \& BAKER AC. 2019. Extensive coral mortality and critical habitat loss following dredging and their association with remotely-sensed sediment plumes. Marine Pollution Bulletin, 145: 185-199.

DU FOUR I \& VAN LANCKER V. 2008. Changes of sedimentological patterns and morphological features due to the disposal of dredge spoil and the regeneration after cessation of the disposal activities. Marine Geology, 255: 15-29.
FIGUEIREDO JR AG \& TESSLER MG. 2004. Topografia e composição do substrato marinho da região Sudeste-Sul do Brasil - Série Documentos Revizee - Score Sul. São Paulo, Brazil: Ulhôa Cintra Comunicação, 64 $\mathrm{pp}$.

FONSECA EM, BAPTISTA NETO JA, McALLISTER J, CRAPEZ M, FERNANDEZ MAS \& BISPO MG. 2009. Bioavailability of heavy metals in Guanabara Bay, Rio de Janeiro (Brazil). Journal of Coastal Research, 56: 802-806.

GIBBS RJ \& ANGELIDIS M. 1989. Effect of Sludge Digestion on Metal Segregation During Ocean Dumping. Marine Pollution Bulletin, 20(10): 503-508.

HALPERN BS, WALBRIDGE S, SELKOE KA, KAPPEL CV, MICHELI F, D'AGROSA C, BRUNO JF, CASEY KS, EBERT C, FOX HE, FUJITA R, HEINEMANN D, LENIHAN HS, MADIN EMP, PERRY MT, SELIG ER, SPALDING M, STENECK R \& WATSON R. 2008. A Global Map of Human Impact on Marine Ecosystems. Science, 319(5865): 948-952.

HARVEY M, GAUTHIER D \& MUNRO J. 1998. Temporal changes in the composition and abundance of the macro-benthic invertebrate communities at dredged material disposal sites in the Anse à Beaufils, Baie des Charleurs, eastern Canada. Marine Pollution Bulletin, 36: 41-55.

KJERFVE B, RIBEIRO CHA, DIAS GTM, FILIPPO AM \& QUARESMA VS. 1997. Oceanographic characteristics of an impacted coastal bay: Baía de Guanabara, Rio de Janeiro, Brazil. Continental Shelf Research, 17: 1609-1643.

KOWSMANN R0. 1979. Sedimentação quaternária da margem continental brasileira e das áreas oceânicas adjacentes. In: Projeto REMAC - Reconhecimento Global da Margem Continental Brasileira. Petrobras, CENPES, vol. 8. Rio de Janeiro, Brazil.

LAZZARI AL, WAGENER ALR, CARREIRA RS, GODOY JMO, CARRASCO G, LOTT CT, MAUAD CR, EGLINTON TI, MCINTYRE C, NASCIMENTO GS \& BOYLE EA. 2019. Climate variability and sea level change during the Holocene: Insights from an inorganic multi-proxy approach in the SE Brazilian continental shelf. Quaternary International, 508: 125-141.

MAHIQUES M, SILVEIRA ICA, SOUSA SHM \& RODRIGUES $M$. 2002. Post-LGM sedimentation on the outer shelf-upper slope of the northernmost part of the São Paulo Bight, southeastern Brazil. Marine Geology, 181: 387-400.

MANAP N \& VOULVOULIS N. 2016. Data analysis for environmental impact of dredging. Journal of Cleaner Production, 137: 394-404.

MELO GV, BAPTISTA NETO JA, MALM 0, FERNANDEZ MAS \& PATCHINEELAM SM. 2014. Composition and behaviour of heavy metals in suspended sediments in a tropical estuarine system. Environmental Earth Sciences, 2: 1-14.

MILLIMAN JD \& SUMMERHAYES CP. 1975. Upper Continental Margin Sedimentation off Brazil. Contributions to Sedimentology, 4: 11-43. 
MONGE-GANUZAS M, CEARRETA A \& EVANS G. 2013. Morphodynamic consequences of dredging and dumping activities along the lower Oka estuary (Urdaibai Biosphere Reserve, southeastern Bay of Biscay, Spain). Ocean \& Coastal Management, 77: 40-49.

NASCIMENTO MTL, SANTOS ADO, FELIX LC, GOMES G, OLIVEIRA SÁ M, CUNHA DL, VIEIRA N, HAUSER-DAVIS RAN, BAPTISTA NETO JA \& BILA DM. 2018. Determination of water quality, toxicity and estrogenic activity in a nearshore marine environment in Rio de Janeiro, Southeastern Brazil. Ecotoxicology and Environmental Safety, 149: 197-202.

POWILLEIT M, KLEINE J \& LEUCHS H. 2006. Impacts of experimental dredged material disposal on a shallow, sublittoral macrofauna community in Mecklenburg Bay (western Baltic Sea). Marine Pollution Bulletin, 52: 386-396.

REBELLO A, HAEKEL W, MOREIRA I, SANTELLI R \& SCHROEDER F. 1986. The fate of heavy metals in an estuarine tropical system. Marine Chemistry, 18: 215-225.

ROBERTS RD, GREGORY MR \& FOSTER MA. 1998. Developing an efficient macrofauna monitoring index from an impact study - a dredge spoil example. Marine Pollution Bulletin, 36: 231-235.

RUMNEY HS, BOLAM SG \& LAW RJ. 2015. Polycyclic aromatic hydrocarbons in sediments at dredged material disposal sites around England: Concentrations in 2013 and time trend information at selected sites 2008-2013. Marine Pollution Bulletin, 92: 180-185.

SMITH SDA \& RULE MJ. 2001. The effects of dredge-spoil dumping on a shallow water soft-sediment community in the Solitary Islands Marine Park, NSW, Australia. Marine Pollution Bulletin, 42: 1040-1048.

SOARES-GOMES A, DA GAMA BAP, BAPTISTA NETO JA, FREIRE DG, CORDEIRO RC, MACHADO W, BERNARDES MC, COUTINHO R,
THOMPSON FL \& PEREIRA RC. 2016. An environmental overview of Guanabara Bay, Rio de Janeiro. Regional Studies in Marine Science, 8: 319-330.

STRONKHORST J, ARIESE F, VAN HATTUM B, POSTMA JF, de KLUIJVER M, DEN BESTEN PJ, BERGMAN MJN, DAAN R, MURK AJ \& VETHAAK AD. 2003. Environmental impact and recovery at two dumping sites for dredged material in the North Sea. Environmental Pollution, 124: $17-31$.

TAUBER F. 2009. Side scan sonar survey of a dumping site in the Mecklenburg Bight (south-western Baltic Sea). Journal of Marine Systems, 75: 421-429.

VAN MAREN DS, VAN KESSEL T, CRONIN K \& SITTONI L. 2014. The impact of channel deepening and dredging on estuarine sediment concentration. Continental Shelf Research, 95: 1-14.

VILELA CG, FIGUEIRA BO, MACEDO MC \& BAPTISTA NETO JA. 2014. Late Holocene evolution and increasing pollution in Guanabara Bay, Rio de Janeiro, SE Brazil. Marine Pollution Bulletin, 79: 175-187.

WARE S, BOLAM SG \& REES HL. 2010. Impact and recovery associated with the deposition of capital dredgings at UK disposal sites: Lessons for future licensing and monitoring. Marine Pollution Bulletin, 60: 79-90.

WIENBERG C \& BARTHOLOMA A. 2005. Acoustic seabed classification in a coastal environment (outer Weser Estuary, German Bight) - a new approach to monitor dredging and dredge spoil disposal. Continental Shelf Research, 25: 1143-1156.

WIENBERG C \& HEBBELN D. 2005. Impact of dumped sediments on subaqueous dunes, outer Weser Estuary, German Bight, Southeastern North Sea. Geo-Marine Letters, 25: 43-53. 